\title{
PENTINGNYA PENDIDIKAN SEKS BAGI ANAK SEBAGAI UPAYA PEMAHAMAN DAN MENGHINDARI PENCEGAHAN KEKERASAN MAUPUN KEJAHATAN SEKSUAL
}

\author{
Farid Wajdi ${ }^{*}$ \\ Asmani Arif 2 \\ ${ }^{1}$ Universitas Sembilanbelas November, Kolaka, Indonesia \\ ${ }^{2}$ Institusi Agama Islam Al-Mawaddah Warrahmah, Kolaka, Indonesia \\ wajdikf83@usn.ac.id $1^{*}$ \\ asma.edu178@gmail.com $^{2)}$
}

Kata Kunci: [Pendidikan seks, pemahaman, pencegahan kekerasan]

Published by:

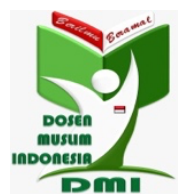

Abstrak: Maraknya perilaku kekerasan, penyimpangan dan kejahatan seksual dalam kehidupan masyarakat dibutuhannya peran para orang tua, pendidik dan masyarakat sekitar melalui Pendidikan seksual dengan cara pemahaman dan pencegahan yang baik dan benar kepada anak-anak sebagai bekal kehidupan selanjutnya. Tujuan penelitian ini adalah untuk memberikan pemahaman, solusi dan pelatihan mengenai pentingnya Pendidikan sesksual bagi anak generasi penerus bangsa guna memahami Pendidikan seksual yang sehat dan upaya mencegah penyimpangan dan kekerasan seksual. Penelitian ini menggunakan metode Pustaka, pengambilan sumber data melalui informasi dan kajian ilmiah berupa media cetak dan elektronik. Hasil penelitian menunjukkan bahwa Pendidikan seksual bagi anak, baik sejak usia mereka masih dini maupun remaja sangat penting dan diperlukan. Karena dengan adanya pemberian pemahaman seksualitas mereka akan lebih memahami dan berhati-hati, sebagai upaya mencegah dan menghindari pelecehan, kekerasan dan perilaku menyimpang seksual.

Copyright (c) 2021 The Author(s)

This article is licensed under CC BY 4.0 License (cc) $\mathrm{BY}$

https://dmi-journals.org/jai/ 


\section{Pendahuluan}

Pendidikan merupakan salah satu sarana bagi keberlangsuangan hidup manusia. Manusia tanpa Pendidikan akan mengalami jalan kebuntuan yang menyebabkan ketidakbaikan kehidupan manusia ke depan. Dewantara menyatakan, pendidikan sebagai pembudayaan perilaku manusia yang beradab dan sikap perjuangan manusia terhadap dua kekuatan yang selalu mengelilingi hidup manusia yaitu kodrat alam dan zaman atau masyarakat (Dewantara, 2013). Sedangkan Wajdi menyatakan, pendidikan sebagai sarana dalam mengatur (mengelola) perilaku dan sikap manusia yang memiliki peran penting guna kehidupan ke depan (Wajdi, 2021).

Kehidupan dewasa ini, kerap terjadi peristiwa-peristiwa yang membuat miris orang tua, pendidik dan masyarakat luas. Salah satu diantaranya pelecehan, kekerasan dan penyimpangan seksual yang dilakukan oleh manusia yang tidak memiliki adab (etika) kehidupan. Berbagai media, terutama media elektronik sesuai dengan perkembangannya saat ini senantiasa memberikan informasi terkait hal tersebut.

Pemahaman yang kurang atau enggan diketahui anak-anak dan remaja yang membutuhkan bimbingan dan Pendidikan dari para pendidik (orang tua dan guru) mengakibatkan dan membuat mereka menjadi sasaran para penjahat kelamin (predator). Lingkungan sekitar kita, bahkan melalui media informasi banyak terjadi kejahatan tersebut. Sehingga, para korban mengalami gangguan kejiwaan berupa trauma, ketakutan dan kecemasan terhadap apa yang dialaminya.

Riset ini berawal dengan masifnya kejahatan-kejahatan seksual yang dilakukan oleh para oknum yang tidak bertanggungjawab terhadap anak, remaja, bahkan seorang istri yang tidak pantas mendapatkannya.

Peristiwa dan kejadian dari berbagai sumber informasi diantaranya, kejadian pelecehan seksual dialami seorang mahasiswi di universitas riau, dugaan ini terjadi pada oknum dosen yang telah melakukan pelecehan seksual di lembaga Pendidikan, korban mengalami trauma dan ketakutan. Dua orang anak di Tangerang telah mengalami pelecehan seksual dan pelaku merupakan seorang oknum guru mengaji. Seorang perempuan yang sedang berbelanja sayur telah mengalami pelecehan seksual yang dilakukan oleh dua orang pengamen di pasar kaget Rawajati. Puluhan laporan pelecehan seksual terjadi di kampus ternama UI, yaitu 39 laporan kekerasan seksual di UI 20192020: 1) 22 merupakan pelecehan seksual secara fisik; 2) 3 merupakan pelecehan seksual secara verbal; 3) 2 merupakan pelecehan seksual secara virtual; 4) 6 merupakan perkosaan; 5) 2 merupakan percobaan perkosaan; 6) 1 merupakan tindakan perbudakan seksual, dan 7) 3 lainnya merupakan intimidasi seksual. Ada pula pelecehan seksual yang dikenal di media sosial sebagai penjahat kelamin, mereka para pelaku menyentuh alat vital para korban layaknya seorang penjambret.

Peristiwa-peristiwa tersebut di atas menggambarkan perlunya upaya pemahaman dan pencegahan bagi anak-anak generasi penerus bangsa, agar tidak mengalami trauma, ketakutan dan bahkan menghindari masa depan yang curam bagi mereka akibat terganggu kejiwaannya terhadap perlakuan yang dialami para korban.

Berdasarkan permasalahan tersebut, penulis berupaya mengkaji pentingnya Pendidikan seks bagi anak-anak sebagai upaya (kunci pencegahan) guna memahami dan 
menghindari perilaku yang dianggap menyimpang dalam norma kehidupan beragama, berbudaya dan berbangsa.

Upaya memberikan pemahaman sebagai cara untuk menghindari perbuatan yang tidak baik atau tidak pantas dalam pandangan maupun norma kehidupan (norma agama, budaya dan bangsa) merupakan peran utama para pendidik. Pendidikan dilakukan dalam berbagai keadaan. Artinya, Pendidikan dilakukan dalam lingkungan keluarga, satuan Pendidikan (sekolah), dan lingkungan masyarakat. Yang dikenal dengan istilah tripusat Pendidikan.

Pendidikan seks (sex education) bagi anak sangat diperlukan, walaupun hal tersebut merupakan hal yang asing bagi anak karena belum masanya mereka lalui. Namun, pemberian pemahana tentang seksualitas sangat berguna dan bermanfaat bagi anak-anak generasi penerus bangsa, sebagai upaya meminimalisir dan mencegah perbuatan menyimpang. Menurut Santelli et al, Pendidikan seks sangat penting untuk memberikan informasi perkembangan dan kesejahteraan seksual yang sehat, sehingga kaum remaja memiliki hak atas informasi yang akurat serta lengkap (Santelli et al., 2017).

Pendidikan seks bagi anak mampu menghindari korban pelecehan seksual (Elok Permatasari, 2017). Pendidikan seksual sejak dini sangat penting diajarkan sebagai Langkah menghindari dan menangani kekerasan seksual pada anak (Lestari \& Herliana, 2020). Pelaksanaan pendidikan seksual melalui Pendidikan bagi anak usia dini penting sebagai upaya pencegahan perbuatan pelecehan seksual (Anggraini et al., 2017). Pendidikan seksual secara dini diawali dari rumah melalui peran orang tua sangat penting dan harus dilaksanakan, karena orang tua memiliki peran utama sebagai role model (Nadeak et al., 2020). Pendidikan seksual dapat efektif melalui peran orang tua dengan memberikan pemahaman perilaku seksual sehat dengan metode ceramah, diskusi dan brosur (Helmi \& Paramastri, 2015). Alangkah bainya pemahaman Pendidikan seks yang diperoleh anak itu secara langsung dari orang tua (Safita, 2013). Peran pendidikan seksual bagi ketahanan psikologi remaja, yaitu:1) menjawab rasa ingin tahu remaja melalui pemberian informasi yang benar terkait seksualitas dan; 2) membentuk sikap guna menghadapi perilaku seksual dini dan pra-nikah (Rinta, 2015). Peningkatan pemahaman bagi orang tua mengenai pendidikan seksual bagi anak melalui berbagai informasi baik media cetak maupun media elektronik (Tampubolon et al., 2019).

Berdasarkan uraian tersebut, maka Pendidikan seksual (sex education) merupakan salah satu sarana dalam memberikan pemahaman tentang Kesehatan alat reproduksi dan upaya pencegahan penyimpangan perilaku seksual dalam kehidupan manusia.

\section{Metode Pelaksanaan}

Riset ini menggunakan metode kepustakaan, peneliti memperoleh sumber data melalui media yang viral maupun disiarkan oleh berbagai media elektronik yang menjadi perhatian masyarakat, khususnya para orang tua, sumber-sumber lain juga peneliti peroleh daripenelitian ilmiah para peneliti terdahulu yang mengkaji tentang Pendidikan seksual. 


\section{Hasil dan Pembahasan}

Pendidikan seksual memang sebuah kajian yang masih tabu secara umum, bahkan para orang tua masih sungkan dan malu mengungkapkan pemahaman tentang Pendidikan seksual. Namun, Pendidikan ini perlu dan sangat penting digencarkan oleh para orang tua di rumah, para pendidik dalam satuan Pendidikan, dan masyarkat sekitar yang peduli terhadap anak-anaknya.

Pengaruh globalisasi jika tidak diantisipasi dengan Pendidikan berupa Pendidikan agama, Pendidikan budaya dan Pendidikan kebangsaan akan memberikan dampak yang kurang baik bagi generasi penerus bangsa. Disinilah perlu dan pentingnya peran orang tua, pendidik, masyarakat dan bahkan pemerintah untuk memberikan edukasi yang baik terhadap peristiwa-peristiwa yang dialami para korban seksualitas yang tidak sehat. Sehingga ada efek jera bagi para pelaku terhadap apa yang diperbuatnya. Karena, jika seorang manusia sudah mengalami trauma dan ketakutan sangat rawan untuk melanjutkan hidupnya jika tidak didampingi dan bahkan dilindungi oleh segenap elemen (orang tua, pendidik, masyarakat dan pemerintah).

Mudahnya akses para pelaku dalam melihat, menyaksikan bahkan mempraktikkan video-video asusila merupakan salah satu penyebab para pelaku melakukan hal yang demikian. Kita sebagai orang tua, pendidik, dan warga masyarakat harus berupaya memberikan pemahaman dan pencegahan yang baik tentang apa itu seksualitas.

Para peneliti yang telah mengkaji pentingnya Pendidikan seks bagi anak diantaranya: 1) Tampubolon dkk tahun 2019 dengan judul "Pengembangan Buku Pendidikan Seksual Anak Usia 1-3 Tahun", menyimpulkan bahwa, sikap dan keterampilan orang tua dalam memberikan pendidikan seksual bagi anak berusia 1-3 tahun di rumah masing-masing melalui kompetensi pengetahuan dan kompetensi sikap, memiliki pemahaman yang tepat mengenai pentingnya memberikan pendidikan seksual dan cara memberikan pendidikan seksual tersebut dan terampil dalam memberikan pendidikan seksual kepada anak sejak dini; 2) Lestari dan Herliana tahun 2020 dengan judul "Implementasi Pendidikan Seksual Sejak Dini Melalui Audio Visual, menyimpulkan bahwa, mayoritas anak sebelum dilakukan implementasi pendidikan seksual sejak dini melalui audio visual belum mengetahui dan belum memahami dalam menunjukkan bagian tubuh mana yang boleh dan tidak boleh disentuh orang lain serta tidak dapat menyebutkan cara menghadapi jika bertemu dengan orang asing. Sedangkan mayoritas setelah dilakukan implementasi pendidikan seksual sejak dini melalui audio visual anak mengetahui dan dapat menunjuk bagian tubuh mana yang boleh dan tidak boleh disentuh orang lain serta dapat menyebutkan cara menghadapi jika bertemu dengan orang asing; dan 3) Permatasari dan Adi tahun 2017 dengan judul "Gambaran Pemahaman Anak Usia Sekolah Dasar Tentang Pendidikan Seksual dalam Upaya Pencegahan Kekerasan Seksual pada Anak", menyimpulkan bahwa, terdapat pengaruh yang signifikan peran guru kelas dalam memberikan pendidikan seksual pada anak terhadap pemahaman anak tentang pendidikan seksual dalam upaya pencegahan kekerasan seksual pada anak usia sekolah dasar.

Berdasarkan hasil penelitian tersebut, maka sangat perlu dan pentingnya Pendidikan seksual bagi anak mulai tingkat usia dini hingga remaja secara massif guna memberikan pemahaman yang lebih baik dan mencegah perilaku seksual yang menyimpang, kekerasan seksual dan kejahatan seksual. Dengan demikian, penulis deskripsikan pemahaman dan pencegahan yang perlu dilakukan berupa Pendidikan seks 
bagi anak-anak generasi penerus kita diantaranya: 1) membangun komunikasi baik dan harmonis antara pendidik (orang tua-guru-dosen, dll) dengan anak; 2) memberikan pemahaman ajaran agama yang baik; 3) memberikan informasi kepada anak tentang lingkungan pergaulan, terutama Batasan antara hubungan laki-laki dengan perempuan; 4) mengawasi dan menginformasikan pengaruh media elektronik yang perlu dihindari; 5) menegaskan kepada anak etika berpakaian yang baik; 6) memberikan informasi dan mengajarkan tentang kesehatan alat reproduksi; 7) memberikan informasi dan pendidikan kepada anak laki-laki dan perempuan bagaimana etika yang baik Ketika nanti memiliki pasangan hidup; dan 8) utamakan baik dan bagusnya perilaku gaya hidup para pendidik (orang tua-guru-dosen, dll) sebagai teladan kehidupan anak-anak generasi penerus bangsa.

Pembahasan penelitian ini dapat kita deskripsikan mengenai pentingnya pendidikan seks bagi anak sebagai upaya pemahaman dan menghindari pencegahan kekerasan maupun kejahatan seksual. Diantara upaya tersebut adalah perlunya peran orang tua, peran pendidik, peran lingkungan sekitar (masyarakat) dan peran pemerintah guna mengantisipasi problem seksualitas yang dilakukan para pelaku penjahat kelamin.

\section{Peran Orang Tua}

Orang tua sebagai pendidik pertama di rumah wajib memberikan Pendidikan yang baik-baik berupa Pendidikan agama, Pendidikan budaya etnisnya dan bahkan Pendidikan mengenai seksualitas bagi anak. Memang Sebagian besar orang tua merasa asing dan enggan membicarakan seksualitas. Padahal pemahaman tersebut sangat penting bagi anak-anak. Tentunya pemberian pemahaman tersebut perlu ada Batasan-batasan yang perlu dikaji. Seperti contoh bagaimana jika laki-laki dan perempuan sebagai makhluk ciptaan Tuhan itu diciptakan berpasang-pasangan dan harus mengikuti ajaran Tuhan dan Nabi-Nya. Pemahaman ini diberikan melalui metode ceramah dan diskusi. Namun, sebagai orang tua harus memahami apa yang harus disampaikan kepada anak-anaknya. Menurut Wajdi et al, orang tua sebagai kunci utama dalam proses pertumbuhan maupun perkembangan perilaku anak (Wajdi et al., 2021). Orang tua harus mengambil sikap dan berperan aktif terhadap Pendidikan seks pada anak, karena orang tua merupakan orang terdekat bagi anak yang memberi rasa aman dan nyaman terhadap komunikasi dan informasi tentang Pendidikan seks (Wahyuni, 2018). Orang tua sangat membutuhkan informasi tentang pemahaman pendidikan seks di sekolah sebagai bekal Pendidikan bagi anak-anaknya agar ada persamaan persepsi tentang Pendidikan seksual yang sehat (Herzig van Wees et al., 2021). Pelecehan seksual yang terjadi pada anak melalui pendidikan pencegahan yang melibatkan ibu (orang tua) sebagai strategi yang paling tepat (Khoori et al., 2020).

\section{Peran Pendidik}

Para pendidik (guru dan dosen) memiliki peran mendidik para partisipan didik dalam satuan Pendidikan di sekolah dan di kampus. Dalam hal ini guru sekolah melalui guru BP atau BK yang terdapat dalam satuan Pendidikan memberikan Pendidikan tambahan diluar jam sekolah dengan memberikan pemahaman seksualitas, seperti masa pubertas, bagaimana sikap anak perempuan terhadap lawan jenisnya, dan sebagainya. Hal ini sangat penting bagi mereka. Sebab sekolah adalah wadah kedua bagi mereka dalam memperoleh pemahaman, ilmu, pengetahuan dan Pendidikan yang baik. Terutama mengani Pendidikan seksual. Begitu pula dosen sebagai pendidik di Pendidikan tertinggi memberikan pencerahan, pemahaman mengenai Pendidikan seks yang terdapat dalam 
materi pokok bahasan perkuliahan untuk mengambil benang merah mengenai Pendidikan seksual. Menurut Suteja dan Riyadi, guru memiliki peran begitu penting dalam memberikan pemahaman berupa pendidikan seksual bagi anak sebagai upaya antisipasi, pengetahuan, pemahaman guna mencegah perilaku seks bebas dan upaya menghindari efek kurang baik (Suteja \& Riyadi, 2019). Pendidikan seks dalam satuan Pendidikan (di sekolah) memiliki peran yang juga sangat penting guna menjaga kesehatan dan kesejahteraan seksual bagi anak (Goldfarb \& Lieberman, 2021).

\section{Peran Masyarakat}

Masyarakat sekitar dalam lingkungan kehidupan manusia, baik itu tokoh seperti tokoh agama, tokoh masyarakat (RT, RW, Lurah, Camat dan Organisasi Kemasyarakatan) memiliki peran yang sangat penting dalam kehidupan sosial. Jika ada gerak-gerik masyarakat yang mencurigakan baik dalam sebuah kos-kosan, hotel, penginapan dan sebagainya perlu ditinjau dan di cek apakah dengan adanya dua orang lawan jenis (lakilaki dan perempuan) merupakan suami istri yang sah atau bukan. Jika tidak maka, masyarakat berhak menindak dengan memberikan sanksi sosial. Bahkan jika da para predator atau penjahat kelamin yang melakukan Tindakan asusila di wilayahnya perlu cegah dan ditindak agar kurangnya korban dan adnya efek jera bagi para pelaku kejahatan tersebut. Tentunya peran penting masyarakat mengenai Pendidikan seksual dengan memberikan penyuluhan dan komunikasi yang baik kepada warga disekitarnya. Menurut Fitriani, dkk menyatakan, pendidikan agama maupun Pendidikan modern cukup memberikan wawasan tambahan, para orang tua (wali murid) lebih siap memberikan Pendidikan seksual kepada anak-anaknya dengan memiliki jawaban dan komunikasi yang baik, benar dan tepat mengenai Pendidikan seksual (E. Fitriani, Yahmun, 2021). Perlunya konsolidasi Pendidikan seks yang sehat secara terbuka (publik) bagi setiap individu, agar para pelaku pelanggaran seksual memperoleh rehabilitasi (program pengobatan) begitupula bagi para pelaku kejahatan seks guna merubah pola pikir (persepsi) tentang seksualitas (Rothwell et al., 2021).

\section{Peran Pemerintah}

Pemerintah selaku pemangku kebijakan dan berwenang mengeluarkan undangundang serta memberikan sanksi atau hukuman melalui alat negara (Polri-TNI) dan pengadilan berperan penting membuat aturan dan Tindakan bagi para pelaku kejahatan, terutama penjahat kelamin (predator) yang telah membuat suram masa depan anak, remaja, dan istri yang mendapat perlakuan tidak baik dari suaminya. Sehingga, perbuatan jahat yang dilakukan para pelaku kejahatan terbalaskan dengan adanya hukuman berdasarkan peraturan pemerintah dan undang-undang tersebut. Walaupun, hukuman yang mereka jalani belum tentu mengobati luka yang dialami korban dan orang tua korban. Bahkan peraturan pemerintah terhadap sanksi yang diberikan kepada para pelaku masih menjadi perdebatan masyarakat. Padahal jika kita yang mengalami terhadapa jatuhnya korban dari salah satu keluarga kita akan mengalami rasa sakit hati yang berkepanjangan. Menurut Amrizal, dkk menyatakan, perlunya sanksi bagi para pelaku kejahatan seksual (predator) terhadap anak dengan menerbitkan kebijakan kriminal (criminalpolicy) dengan memberi sanksi berat dan membuat jera (detterence) pelaku (A. Amrizal, I. S. Utami, 2019).

Berdasarkan uraian tersebut, maka pentingnya peran para orang tua, pendidik, masyarkat, maupun pemerintah terhadap gejala dan peristiwa perilaku menyimpang dalam hal seksualitas melalui Pendidikan seks (seks education) yang baik, tepat dan benar 
sebagai upaya memberikan pemahaman tentang Kesehatan alat reproduksi, dan upaya pencegahan perilaku menyimpang seksual (pemerkosaan, kekerasan seksual dan seks bebas).

\section{Kesimpulan}

Kejahatan yang terjadi pada para korban kejahatan seksual masih begitu banyak setiap tahunnya disekitar kehidupan kita. Walaupun berbagai upaya telah dilakukan guna mencegah kejahatan tersebut. Namun, upaya dan usaha yang massif dan tanpa rasa bosan, kita perlu memberikan Pendidikan berupa pemahaman dan pencegahan perilaku seks menyimpang dan kejahatan seksual. Pendidikan seksual memang sebuah pembahasan yang dianggap tabu oleh masyarakat luas. Akan tetapi, jika kita tidak memberikan pemahaman berupa pengetahuan seksual yang baik dan sehat sebagai upaya pencegahan dari bahaya tersebut akan berakibat fatal bagi para korban pelecehan, kekerasan dan penyimpangan seksual. Bagi para orang tua, pendidik, masyarakat dan bahkan pemerintah yang peduli, tentu akan mengambil langkah memberikan edukasi yang baik, benar dan sehat mengenai Pendidikan seks (seks education). Dengan demikian, Pendidikan seksual merupakan ajaran pemahaman baik mengenai hubungan antara lawan jenis (laki-laki dan perempuan) berdasarkan ajaran agama, budaya, dan anjuran negara agar dalam pelaksanaannya terhindar perilaku yang tidak baik menurut norma agama dan budaya bangsa. Sehingga, peran orang tua, pendidik, masyarakat dan pemerintah harus ekstra dalam memberikan Pendidikan seksual bagi anak penerus generasi bangsa berdasarkan Batasan-batasan yang perlu diajarkan dalam kehidupan mereka, agar kehidupan ke depan mereka siap dan mampu menghadapi apa yang menjadi rintangan dan tantangan hidupnya.

\section{Referensi}

A. Amrizal, I. S. Utami, F. K. (2019). Kontroversi Kebijakan Kriminal Pemerintah Tentang Praktek Sanksi Kebiri Bagi Pelaku Kejahatan Seksual. Jurnal Surya Kencana Dua : Dinamika Masalah Hukum Dan Keadilan, 6(2), 829-849. https://doi.org/10.32493/SKD.v6i2.y2019.3991

Anggraini, T., Riswandi, \& Ari, S. (2017). Pendidikan Seksual Anak Usia Dini: Aku dan Diriku. Jurnal Pendidikan Anak, 3(2), 1-14. http://jurnal.fkip.unila.ac.id/index.php/PAUD/article/view/12980

Dewantara, K. H. (2013). Ki Hadjar Dewantara: Pendidikan Pemikiran, Konsepsi, Keteladanan, Sikap Merdeka I (Pendidikan). Majelis Luhur Persatuan Tamansiswa.

E. Fitriani, Yahmun, E. S. (2021). Penyuluhan Dan Pelatihan Komunikasi Tentang Pendidikan Seks Untuk Anak Usia Dini. JPM Pambudi, 5(1), 1-9. https://doi.org/10.33503/pambudi.v5i01.1359

Elok Permatasari, G. S. A. (2017). Gambaran Pemahaman Anak Usia Sekolah Dasar Tentang Pendidikan Seksual Dalam Upaya Pencegahan Kekerasan Seksual Pada Anak. The Indonesian Journal of Health Science, 9(1), 70-79. https://doi.org/10.32528/the.v9i1.1264 
Goldfarb, E. S., \& Lieberman, L. D. (2021). Three Decades of Research: The Case for Comprehensive Sex Education. Journal of Adolescent Health, 68(1), 13-27. https://doi.org/10.1016/j.jadohealth.2020.07.036

Helmi, A. F., \& Paramastri, I. (2015). Efektivitas Pendidikan Seksual Dini Perilaku Seksual Sehat. Jurnal Psikologi, 25(2), 25-35. https://doi.org/10.22146/jpsi.7502

Herzig van Wees, S., Fried, S., \& Larsson, E. C. (2021). Arabic speaking migrant parents' perceptions of sex education in Sweden: A qualitative study. Sexual and Reproductive Healthcare, 28(1), 1-5. https://doi.org/10.1016/j.srhc.2021.100596

Khoori, E., Gholamfarkhani, S., Tatari, M., \& Wurtele, S. K. (2020). Parents as Teachers: Mothers' Roles in Sexual Abuse Prevention Education in Gorgan, Iran. Child Abuse and Neglect, 109(8), 104695. https://doi.org/10.1016/j.chiabu.2020.104695

Lestari, N. E., \& Herliana, I. (2020). Implementasi Pendidikan Seksual Sejak Dini Melalui Audio Visual. Jurnal Pengabdian Masyarakat Indonesia Maju, 1(1), 29-33. https://doi.org/10.33221/jpmim.v1i01.566

Nadeak, B., Sormin, E., Naibaho, L., \& Deliviana, E. (2020). Sexuality in Education Begins in The Home (Pendidikan Seksual Berawal Dalam Keluarga). Jurnal Comunit $\tilde{A}$ Servizio, 2(1), 254-264. https://doi.org/10.33541/cs.v2i1.1651

Rinta, L. (2015). Pendidikan Seksual Dalam Membentuk Perilaku Seksual Positif Pada Remaja Dan Implikasinya Terhadap Ketahanan Psikologi Remaja. Jurnal Ketahanan Nasional, 21(3), 163-174. https://doi.org/10.22146/jkn.15587

Rothwell, M., Fido, D., \& Heym, N. (2021). Perceptions around adult and child sex offenders and their rehabilitation as a function of education in forensic psychology independent of traditionalism and perpetrator sex. Forensic Science International: Mind and Law, 2(8), 100039. https://doi.org/10.1016/j.fsiml.2020.100039

Safita, R. (2013). Peranan Orang Tua dalam Memberikan Pendidikan Seksual pada Anak. Jurnal Edu-Bio, 4(3), 32-40. http://portalgaruda.fti.unissula.ac.id/index.php?ref=browse\&mod=viewarticle \&article $=252706$

Santelli, J. S., Kantor, L. M., Grilo, S. A., Speizer, I. S., Lindberg, L. D., Heitel, J., Schalet, A. T., Lyon, M. E., Mason-Jones, A. J., McGovern, T., Heck, C. J., Rogers, J., \& Ott, M. A. (2017). Abstinence-Only-Until-Marriage: An Updated Review of U.S. Policies and Programs and Their Impact. Journal of Adolescent Health, 61(3), 273-280. https://doi.org/10.1016/j.jadohealth.2017.05.031

Suteja, J., \& Riyadi, M. (2019). Revitalisasi Peran Orang Tua Dan Guru Dalam Memberikan Pendidikan Seks Pada Anak. Equalita: Jurnal Pusat Studi Gender Dan Anak, 1(1), 38-50. https://doi.org/10.24235/equalita.v1i1.5154 
Tampubolon, G. N., Nurani, Y., \& Meilani, S. M. (2019). Pengembangan Buku Pendidikan Seksual Anak Usia 1-3 Tahun. Jurnal Obsesi: Jurnal Pendidikan Anak Usia Dini, 3(2), 527. https://doi.org/10.31004/obsesi.v3i2.243

Wahyuni, D. (2018). Peran Orang Tua dalam Pendidikan Seks Bagi Anak untuk Mengantisipasi LGBT. Quantum: Jurnal Kesejahteraan Sosial, 14(1), 23-32. https://ejournal.kemensos.go.id/index.php/Quantum/article/view/1747

Wajdi, F. (2021). Manajemen Perkembangan Siswa SD Melalui Peran Guru Dan Orang Tua Pada Masa Pandemi. JAMP: Jurnal Adminitrasi Dan Manajemen Pendidikan, 4(1), 41-50. https://doi.org/10.17977/um027v4i12021p41

Wajdi, F., Wahyono, E., \& Arif, A. (2021). Management of Student Development on The Impact of Smartphones Through the Role of Parents During the Pandemic. Journal of Educational Science and Technology (EST), 7(2), 155-162. https://doi.org/10.26858/est.v7i2.19361 